Relations industrielles

Industrial Relations

\title{
Cost of Living Adjustments
}

\section{Earl F. Beach}

Volume 29, numéro 3, 1974

URI : https://id.erudit.org/iderudit/028535ar

DOI : https://doi.org/10.7202/028535ar

Aller au sommaire du numéro

\section{Éditeur(s)}

Département des relations industrielles de l'Université Laval

ISSN

0034-379X (imprimé)

1703-8138 (numérique)

Découvrir la revue

Citer cet article

Beach, E. (1974). Cost of Living Adjustments. Relations industrielles / Industrial Relations, 29(3), 602-605. https://doi.org/10.7202/028535ar

Tous droits réservés (C Département des relations industrielles de l'Université Laval, 1974
Ce document est protégé par la loi sur le droit d'auteur. L’utilisation des services d'Érudit (y compris la reproduction) est assujettie à sa politique d'utilisation que vous pouvez consulter en ligne.

https://apropos.erudit.org/fr/usagers/politique-dutilisation/ 


\title{
COST OF LIVING ADJUSTEMENTS
}

\author{
EARL F. BEACH
}

In this strange new world of continuing inflation, we must be increasingly inventive. One kind of adaptation that may be adopted a little too quickly, however, is the technique of adjusting wages and salaries upward in proportion to changes in the official Index of Consumer Prices. We offer some thoughts on the implications of such adjustments.

During World War II there was much discussion ${ }^{1}$ of the index of consumer prices as a measure of «cost of living». It was agreed that the former is a measure of price change alone, whereas the latter entailed some change in quantity or quality. For example, when the dollar shirt disappeared and inexpensive housing became unavailable, consumers were forced to lay out more money to obtain at least the equivalent of their former level of living. Thus, changes in « cost of living » entail more than pure price changes. ${ }^{2}$

The index of Consumer Prices is a measure of the change in the cost of buying a fixed basket of goods that is purchased by a typical urban worker family of average income. If that family saves nothing, but spends all of its income on the basic reference basket, and if the cost of the basket increases by 10 per cent, that family must have an increase in earnings of 10 per cent to be able to enjoy the same basket of goods.

However, as the average level of prices change, there are relative changes among the elements of the basket. Our hypothesized family may, therefore, change its selection of goods and improve its real income. Thus, for such a family, to maintain its real income, the increase in its money income need be something less than the increase in the price index. How much less, would be very difficult to say in general. It would depend on the amount of change among the elements and the possibilities of substitution among them. The significant point is, however, that to increase the money income pari passu with the increase in the price index tends to increase the inflationary pressures by putting more money into circulation than is necessary to maintain the real incomes of the worker. ${ }^{3}$

* Earl F. Beach, Professor, Department of Economics, McGill University.

1 The index of consumer prices continues to be thought of as a measure of cost of living. See, for example, K. W. ROTHSCHILD, The Theory of Wages, (Oxford, 1954) esp. pp. 159-162.

2 J. BLACKMAN, Wage Determination (Van Nostrand, 1959) p. 135.

3 We need not here concern ourselves about some troublesome questions of the measurement of real income. See M. FRIEDMAN, Price Theory (Aldine 1962) p. 52. 
Consider a family whose income is less than the average mentioned above. Such a family, of the same size composition, will have less options available because its needs will press more heavily on the limitations of income. For them it is less easy to take advantage to the increased opportunities presented by the variety of changing prices. It is therefore important for their earnings to increase almost as much as the increase in the general level of prices.

For families whose earnings are above average, the opportunities for substitution are correspondingly greater. ${ }^{4}$ However, inasmuch as the index does not truly measure changes relevant to them, it is difficult to be specific. For example, wealthy families employ more clomestic servants, and if the cost of such service increases more rapildy than prices in general, such an income group will suffer relatively unless such loss is more than offset by new opportunities which they are in a good position to utilize.

In sum, it is not necessary to increase wages and salaries in proportion to increases in the Index of Consumer Prices in order to maintain the real income for the average income family. To do so is to add to inflationary pressures. As average incomes increasingly exceed a «subsistence level » this flexibility increases; thus, it is important to increase welfare cheques in proportion, but not senior salaries or wages of highly paid craft workers. ${ }^{5}$

\section{REAL WAGES}

For many years, « real wages » have been measured by dividing a series of money wages by a series measuring changes in consumer prices. ${ }^{6}$ This has no doubt increased our ready acceptance of the measure. It is the best measure we have, but its use should be prefered by the observation some bias may result. In particular, the resulting improvement in real wages will always be greater (or the decrease will be less) than the quotient, unless all prices change in exactly the same proportion. Whenever there is some dispersion among the price changes, the consumers can take advantage of this diversity of change; and the greater the diversity, the greater will be the downward bias in the usual measurement.

The actual amount of bias is not easily estimated. A situation can be envisioned in which the quotient of the two series shows a decrease,

4 BACKMAN, op. cit. p. 149 and Chap. 7.

5 BACKMAN, J., op. cit., gives an account of Canadian experiences with escalation clauses in union contracts, pp. 143, 4.

6 See, for example, ROTHSCHILD, op. cit., and BLACKMAN, op. cit., Chap. 6. 
and yet the real incomes of many of the consumers - perhaps most of them - could actually increase. The families would differ, of course, depending upon their tastes, and the resulting propensities to substitute goods for others.

statistical theory suggests that the situation is even more complicated. It is well known that when prices are moving upward, the distribution of price relatives tends to be positively skewed, because a few of the prices move much more than all of the others. In such a situation, the arithmetic mean ${ }^{7}$ is pulled up inordinately, giving an upward bias relative to say, the geometric mean or the median of the distribution of price relatives. In the early discussions of price indexes, the geometric mean was favoured by many just because it is a more apprpriate average of a distribution of ratios than is an arithmetic mean. The power of the argument was lessened when prices stopped rising after World War I.

It may be noted that we are concerned with the ratio of two arithmetic means, and both distributions are of price change - one of wage rates, and one of consumer prices. We must first consider the biases of the averages, which would depend upon skewnesses of their distributions. That is, it may be presumed that the distribution with the greater skewness will have more upward bias in its arithmetic mean. Since the skewness of such distributions is likely to be related to their dispersion, we may further presume that mean which changes more is likely to have more upward bias. We conclude that the resulting quotient will be overstated when it rises, and understated when it falls.

This relation is but part of the total question of bias with which we are concerned. In addition to the bias which results from the type of average used to represent the distributions, there is a further bias discussed earlier - a bias which results from the freedom to select purchases from a variety of price changes.

Suppose that all families made purchases in proportion to the reference basket of goods at all times. Then the price index would be precisely relevant to all families. If the two arithmetic means were equally biased, the resulting measure would be precisely what was wanted. However, consumers change their purchases in order to take advantage of prices which increase less rapidly. Thus, we have an upward «selection » bias in our measure, which must be compounded with the «type » bias.

7 The arithmetic mean is generally used in averaging wage rates; and, of course, it is impled when the total wage bill is divided by the number employed. The arithmetic mean is also implied in the use of the weighted aggregate price index formula, because any form of weighted aggregate formula can be expressed in terms of weighted arithmetic mean of price relatives. 
It may be possible to make some summary judgement of the result. 8 If wages and prices change at about the same rate, so that the quotient changes little, then the «type » biases will tend to offset each other, and the bias resulting from «consumer freedom > will produce a downward bias - that is, the measure of « real wage » will be too low. This net bias is likely to be reversed when wages increase much more rapidly than prices, so that the «type » bias in the numerator offsets the «type " bias in the denominator by more than enough to offset the third bias which results from «consumer freedom». This would happen only if « real wages 》 were increasing rapidly. ${ }^{9}$

Collection INSTRUMENTS DE TRAVAIL

publiée sous la direction de GÉRARd Dion

TABLEAUX ANALYTIQUES DE DÉCISIONS

D'ARBITRES DES GRIEFS DU QUÉBEC

$1961-1973$

Alain Barré - Gilles Grenier - Danielle Roy

sous la direction de Me Pierre Verge

Faculté de droit

Université Laval

1 volume, 100 pages - Prix : $\$ 2.50$

DÉPARTEMENT DES RELATIONS INDUSTRIELLES UNIVERSITÉ LAVAL

Québec, P.Q., CANADA

G1K 7P4

8 It would appear from this argument that the publication of official price indexes should be accompanied by measures of dispersion and skewness of the underling distributions - perhaps on a quarterly basis.

9 There are, of course, other reasons why the measures may be inadequate, such as the proper use of wage rates, the question of time worked, etc., a discussion of which will be found in any good textbook of labour economics. 